\title{
EKSPERIMENTASI PEMBELAJARAN BERBASIS TIK MENGGUNAKAN METODE DISCOVERY LEARNING DENGAN PEER ASSESSMENT DI KELAS VIII SMP NEGERI 14 BANJARMASIN
}

\author{
Asy'ari $^{1}$ \& M. Rizki Zulkarnain ${ }^{2}$
}
1. Pendidikan Teknologi Informasi STKIP PGRI Banjarmasin asyari153@stkipbjm.ac.id (085248587493)

2. Pendidikan Teknologi Informasi STKIP PGRI Banjarmasin m.rizki.z@gmail.com (0816216969)

\begin{abstract}
ABSTRAK
Tujuan penelitian ini adalah untuk mengetahui efektivitas pembelajaran berbasis TIK menggunakan metode discovery learning disertai dengan peer assessment terhadap hasil belajar siswa. Penelitian ini merupakan penelitian eksperimental semu dengan desain faktorial $3 \times 3$. Populasinya adalah siswa kelas VIII SMP Negeri 14 Banjarmasin tahun pelajaran 2017/2018. Sampel dalam penelitian ini berjumlah 93 orang diambil dari siswa kelas VIII D, VIII E, dan VIII F SMPN 14 Banjarmasin. Uji prasyarat meliputi uji normalitas dengan menggunakan metode uji Lilliefors dan uji homogenitas menggunakan metode Bartlett. Teknik analisis data yang digunakan adalah uji ANOVA dua jalan dengan sel tak sama. Berdasarkan uji hipotesis, diperoleh kesimpulan bahwa hasil belajar siswa yang diberi perlakuan model pembelajaran berbasis TIK menggunakan metode discovery learning disertai dengan peer assessment lebih baik dari hasil belajar siswa yang diberi model pembelajaran berbasis TIK menggunakan metode discovery learning dan model pembelajaran konvensional. Selain itu, hasil belajar siswa yang diberi perlakuan model pembelajaran berbasis TIK menggunakan metode discovery learning lebih baik dari hasil belajar siswa yang diberi model pembelajaran konvensional.
\end{abstract}

Kata Kunci: Pembelajaran Berbasis TIK, Discovery Learning, Peer Assessment, Gaya Belajar

\section{PENDAHULUAN}

\section{A. Latar Belakang Masalah}

Pendidikan memiliki peranan yang sangat penting dalam menghadapi era globalisasi serta kemajuan Ilmu Pengetahuan dan Teknologi (IPTEK). Untuk menghadapi hal tersebut pemerintah Indonesia melakukan penyempurnaan kurikulum yang dinamakan kurikulum 2013. Kurikulum ini bertujuan untuk mempersiapkan manusia Indonesia agar memiliki kemampuan hidup sebagai pribadi dan warga negara yang beriman, produktif, kreatif, inovatif, dan afektif serta mampu berkontribusi pada kehidupan bermasyarakat, berbangsa, bernegara, dan peradaban dunia.

Matematika merupakan salah satu mata pelajaran yang tercantum dalam kurikulum dan diberikan pada setiap jenjang pendidikan, mulai dari jenjang 
pendidikan terendah sampai jenjang pendidikan tertinggi. Salah satu jenjang pendidikan yang mempelajari matematika adalah Sekolah Menengah Pertama (SMP) sederajat. Berdasarkan peraturan Menteri Pendidikan dan Kebudayaan nomor 68 tahun 2013 bahwa beberapa kompetensi dasar yang harus dimiliki siswa Sekolah Menengah Pertama (SMP) sederajat pada mata pelajaran matematika adalah: (1) Menunjukkan sikap logis, kritis, analitik, konsisten dan teliti, bertanggung jawab, responsif, dan tidak mudah menyerah dalam memecahkan masalah; (2) Memiliki rasa ingin tahu, percaya diri, dan ketertarikan pada matematika serta memiliki rasa percaya pada daya dan kegunaan matematika, yang terbentuk melalui pengalaman belajar; (3) Memiliki sikap terbuka, santun, objektif, menghargai pendapat dan karya teman dalam interaksi kelompok maupun aktivitas sehari-hari. Diharapkan dengan tujuan tersebut siswa dapat memahami materi matematika, sehingga kompetensi yang diharapkan dapat tercapai secara maksimal.

Sistem pembelajaran konvensional di sekolah saat ini diyakini kurang efektif, konsep-konsep kemampuan otak, kecerdasan, dan kreativitas telah berkembang dengan pesat seiring dengan kemajuan dalam bidang teknologi dan komunikasi. Perkembangan tersebut memberikan pengaruh terhadap penguatan yang ingin mengoreksi kelemahan dan kekurangan yang ada pada sistem pembelajaran konvensional. Dalam sistem konvensional, proses transfer of knowledge dilakukan dengan menggunakan papan tulis sebagai sarana utama, ruangan dikelola dengan format yang statis dan guru menjadi satu-satunya informan yang expect dalam bidangnya (teacher centered). Di era globalisasi saat ini TIK (Teknologi Informasi dan komunikasi) menjadi kebutuhan yang mendasar dalam menentukan kualitas dan efektivitas proses pembelajaran. Dryden dan Vos (2003) menyimpulkan dari hasil penelitian mereka bahwa dalam sistem pendidikan yang terbukti berhasil, citra diri ternyata lebih penting dari materi pelajaran. Dengan demikian, konsep pendidikan masa depan ialah diarahkan kepada bagaimana membangkitkan gairah siswa untuk belajar secara menyenangkan (how student learn). Salah satu pendekatan dan metode yang dapat digunakan untuk meningkatkan aspek tersebut ialah dengan pemanfaatan information and comunication technology (ICT) dalam proses pembelajaran. Mean dalam (Suryadi, 2007) menerangkan bahwa kebutuhan masyarakat persekolahan untuk memanfaatkan teknologi dalam pembelajaran merupakan bagian dari reformasi pembelajaran. Selain membantu menciptakan kondusi belajar yang kondusif bagi siswa, peran penting dari teknologi informasi dan komunikasi dalam proses pembelajaran adalah menyediakan seperangkat media dan alat (tool) untuk mempermudah dan mempercepat pekerjaan siswa, serta tentu saja memberi keterampilan penggunaan teknologi tinggi (advance skill) (Suryadi, 2007: 92). Selain itu, antara siswa dan sumber-sumber belajar dapat terjadi kapan saja dan di mana saja tidak terbatas oleh ruang dan waktu (space and time), serta proses penyampaian dan penyajian materi pembelajaran maupun gagasan dapat menjadi lebih menarik dan menyenangkan. Dengan demikian, kehadiran dan kemajuan ICT di era komunikasi global saat ini telah memberikan peluang dan perluasan interaksi antara guru dan siswa, interaksi tidak hanya terbatas di ruang kelas saja. Sehingga di rumah siswa dapat mengualangi materi dengan baik. Untuk itu, guru dapat memanfaatkan berbagai jenis media secara bersamaan dalam bentuk multimedia pembelajaran. Penggunaan 
multimedia interaktif yang memuat komponen audio-visual untuk penyampaian materi pembelajaran dapat menarik perhatian siswa untuk belajar, dan juga dapat memberikan kesempatan kepada siswa untuk melakukan eksperimen semu dan ekplorasi sehingga memberikan pengalaman belajar daripada hanya sekedar mendengar uraian guru. Selanjutnya, kehadiran media dalam proses pembelajaran memiliki makna yang sangat urgen, ketidakjelasan materi yang disampaikan dapat dibantu dengan menghadirkan media sebagai perantara. Kerumitan materi yang akan disampaikan kepada anak dapat disederhanakan dengan media. Selain itu, media dapat mewakili apa yang kurang mampu diucapkan seorang guru melalui kata-kata atau kalimat tertentu. Bahkan materi yang abstrak dapat dikonkretkan melalui media.

Dalam kegiatan pembelajaran guru merupakan komponen proses yang utama dalam penyelenggaraan pendidikan. Seperti yang ditulis Looney (2009: 6) bahwa guru sebaiknya mengambil peran yang berbeda, yaitu tidak hanya mengajar "di depan kelas" tetapi supaya siswa terlibat aktif dalam proses pembelajaran, siswa melakukan penyelidikan atau penemuan mereka sendiri dan mengembangkan solusi. Kemudian guru dan siswa dapat menyesuaikan program dengan kebutuhan pembelajaran dan minat siswa secara individu. Balim (2009: 2) juga berpendapat bahwa salah satu metode yang sesuai dengan pendekatan konstruktivisme adalah pembelajaran discovery seperti yang dituliskan dalam jurnalnya sebagai berikut : Today, it is believed that methods in accordance with the constructivist approach in which the students learn more effectively by constructing their own knowledge, should be used. One of these methods is discovery learning. (Saat ini, diyakini bahwa metode yang sesuai dengan pendekatan konstruktivis dimana siswa belajar lebih efektif dengan membangun pengetahuan mereka sendiri, harus digunakan. Salah satu metode ini adalah pembelajaran discovery). Lebih lanjut Balim (2009:16) dalam hasil penelitian menyimpulkan bahwa "Dengan menggunakan metode pembelajaran discovery, yang merupakan salah satu dari berbagai metode pengajaran dimana siswa aktif dan guru membimbing mereka dapat meningkatkan hasil belajar dan keterampilan belajar siswa". Selanjutnya hasil penelitian yang dilakukan oleh Meyer dalam Jamilah (2013: 4) menunjukkan bahwa proses penemuan (discovery) dalam pembelajaran akan membantu siswa untuk memahami dan menganalisis proses kreativitas dan pengambilan keputusan dari temuannya. Dari pendapat-pendapat tersebut supaya siswa terlibat aktif dalam pembelajaran dan membangun pengetahuannya sendiri maka diterapkan metode penemuan (discovery) dalam pembelajaran, guru mengajak agar siswa benar-benar aktif dalam pembelajaran dengan membimbing siswa dalam menemukan sendiri konsep dari materi yang dipelajarinya, sehingga pembelajaran menjadi lebih bermakna dan memungkinkan siswa untuk menguasai tujuan pembelajarannya. Hal ini kemungkinan besar dapat menyebabkan prestasi belajar siswa lebih meningkat.

Pada kesempatan yang lain, proses penilaian juga layak menjadi sorotan ketika terjadi ketimpangan dalam dunia pendidikan. Apabila dicermati sebenarnya praktik penilaian yang dilakukan secara tepat akan menghasilkan hasil belajar yang meningkat, yakni penilaian yang melibatkan siswa. Seperti yang diungkapkan oleh Nick (2010) bahwa "in the context of student assessment, innovation aims to produce students who are deep rather than surface learners, highly motivated, equipped with a range of transferable skills, active and reactive participants in the learning 
process". Penilaian memiliki pengaruh penting pada satu strategi, motivasi, dan hasil belajar siswa. Oleh sebab itu, diperlukan paradigma baru dalam penilaian supaya penilaian merupakan suatu kegiatan yang termasuk dalam proses pembelajaran sedemikian sehingga kegiatan penilaian dapat membantu dalam meningkatkan kualitas pembelajaran. Salah satu tujuan utama penilaian ialah untuk memberikan umpan balik kepada siswa. Penegasan lebih lanjut terdapat dalam lampiran Peraturan Menteri Pendidikan Nasional Nomor 20 Tahun 2007 tanggal 11 Juni 2007 tentang Standar Penilaian Pendidikan pada poin E penilaian oleh pendidik, butir keenam menjelaskan mengenai kegiatan mengembalikan hasil pemeriksaan pekerjaan siswa disertai balikan/komentar yang mendidik serta pada butir ketujuh yang intinya memanfaatkan hasil penilaian untuk perbaikan pembelajaran. Peer assessment merupakan cara penilaian hasil belajar yang berpusat pada siswa dan dapat dilakukan untuk penilaian formatif. Metode penilaian peer assessment dapat diterapkan untuk menilai kemampuan kognitif maupun kemampuan non kognitif siswa. Penggunaan metode penilaian peer assessment ditujukan untuk memperoleh feedback bagi peserta didik sehingga dapat meningkatkan proses dan hasil belajar siswa sehingga tujuan pembelajaran dapat tercapai dengan optimal. Hal lain yang perlu diperhatikan agar siswa berhasil dalam belajar metematika adalah karakteristik dan kondisi siswa. Karakteristik siswa yang dimaksud disini antara lain: kemampuan awal, motivasi dan gaya belajar. Gaya belajar dari seorang siswa juga perlu diperhatikan. Seorang guru yang baik tentu tidak akan langsung memvonis siswa yang nilainya jelek adalah siswa yang tidak bisa. Guru harus mencari informasi kenapa siswa yang bersangkutan mendapat nilai yang jelek. Terkait dengan hal tersebut, informasi penting yang perlu diketahui guru antara lain terkait dengan gaya belajar siswa.

Melalui permasalahan yang muncul, maka dalam penelitian ini yang menjadi pokok permasalahan, yaitu berkaitan dengan inovasi model pembelajaran, paradigma tentang penilaian dan pemilihan model pembelajaran. Artikel ini merupakan bagian dari hasil penelitian yang dibiayai oleh Kementerian Riset, Teknologi, dan Pendidikan Tinggi melalui hibah Penelitian Dosen Pemula (PDP) tahun anggaran 2018 dengan judul "Pengembangan Model Pembelajaran Berbasis TIK Menggunakan Metode Discovery Learning dengan Peer Assessment Pada Pembelajaran Matematika Ditinjau dari Gaya Belajar Siswa Kelas VIII SMP Negeri di Kota Banjarmasin Tahun Ajaran 2017/2018". Data hasil penelitian dalam artikel ini dibatasi pada populasi siswa kelas VIII SMPN 14 Banjarmasin dan sampel yang digunakan adalah siswa kelas VIII D, VIII E, dan VIII F SMPN 14 Banjarmasin.

\section{B. Rumusan Masalah}

Berdasarkan latar belakang masalah di atas, maka rumusan masalah yang disajikan dalam artikel ini adalah "manakah yang memberikan hasil belajar lebih baik, model pembelajaran berbasis TIK menggunakan metode discovery learning, model pembelajaran berbasis TIK menggunakan metode discovery learning dengan peer assessment atau model pembelajaran konvensional?". 


\section{Tujuan Penelitian}

Sesuai dengan rumusan masalah di atas, maka tujuan penelitian yang disajikan dalam artikel ini adalah untuk mengetahui model pembelajaran mana yang memberikan hasil belajar lebih baik diantara model pembelajaran berbasis TIK menggunakan metode discovery learning, model pembelajaran berbasis TIK menggunakan metode discovery learning dengan peer assessment atau model pembelajaran konvensional.

\section{METODE PENELITIAN}

Jenis penelitian yang digunakan adalah penelitian dan pengembangan (research and development) sedangkan prosedur penelitian mengacu kepada prosedur $\mathrm{R}$ dan $\mathrm{D}$ yang dikemukakan oleh Borg dan Gall dengan beberapa modifikasi. Berikut akan diuraikan langkah-langkah penelitian yang dilakukan: (1) Pengembangan model pembelajaran berbasis TIK menggunakan metode discovery learning dengan peer assessment. Pengembangan model dalam penelitian ini dimaksudkan untuk mendapatkan suatu pengembangan model pembelajaran berbasis TIK menggunakan metode discovery learning dengan peer assessment yang dapat dipraktikkan secara nyata dalam proses belajar mengajar. Adapun tahapan dalam pengembangan model terdiri dari tujuh tahap, yaitu : (a) Studi literatur; (b) Perencanaan pengembangan model pembelajaran berbasis TIK menggunakan metode discovery learning dengan peer assessment; (c) Focus Group Discussion (FGD); (d) Pembuatan prototipe model; (e) Validasi model, (f) Uji coba model; (g) Penetapan model. (2) Uji efektivitas model. Pada uji efektivitas model, dilakukan komparasi hasil belajar siswa yang dikenai pengembangan model pembelajaran berbasis TIK menggunakan metode discovery learning dengan peer assessment dengan siswa yang tidak dikenai model tersebut. Uji efektivitas model ini adalah penelitian eksperimental semu (quasiexperimental research). Pada uji efektivitas ini dilakukan sebanyak enam kali pembelajaran, dan satu kali untuk ujian. Manipulasi variabel dalam penelitian ini dilakukan pada variabel bebas yaitu pengembangan model pembelajaran berbasis TIK menggunakan metode discovery learning dengan peer assessment yang dikenakan terhadap kelas eksperimen pertama, pengembangan model pembelajaran berbasis TIK menggunakan metode discovery learning yang dikenakan terhadap kelas eksperimen kedua, dan model pembelajaran konvensional dikenakan terhadap kelas kontrol. Penelitian ini menggunakan penelitian eksperimental semu dengan desain fakatorial $3 \times 3$. Dalam artikel ini populasi yang digunakan dan dianalisis adalah seluruh siswa kelas VIII SMPN 14 Banjarmasin tahun pelajaran 2017/2018. Kemudian diambil tiga kelas secara acak untuk dijadikan sampel dan akan diberikan perlakuan yang berbeda, yaitu model pembelajaran berbasis TIK menggunakan metode discovery learning dengan peer assessment, pembelajaran berbasis TIK menggunakan metode discovery learning, dan pembelajaran konvensional. Sampel penelitian yang terpilih adalah kelas VIII D, VIII E, dan VIII F. Sampel dalam penelitian ini berjumlah 93 siswa yang terdiri dari 31 siswa pada kelas eksperimen satu (VIII E), 32 siswa pada kelas eksperimen dua (VIII D) dan 30 siswa pada kelas kontrol (VIII F). Dalam penelitian ini terdapat dua variabel bebas yaitu model pembelajaran dan gaya belajar siswa dan satu variabel terikat yaitu hasil belajar matematika. Dalam artikel ini hanya disajikan 
variabel bebas model pembelajaran dan variabel terikat hasil belajar matematika siswa.

Teknik pengumpulan data menggunakan metode dokumentasi, angket, dan tes. Metode dokumentasi digunakan untuk mengumpulkan data kemampuan awal siswa, metode tes digunakan untuk mengumpulkan data hasil belajar, dan angket gaya belajar siswsa digunakan untuk mengumpulkan data gaya belajar siswa. Instrumen yang digunakan dalam penelitian ini berupa tes objektif bentuk pilihan ganda pada materi bangun ruang (kubus dan balok) dan angket gaya belajar siswa (untuk membedakan gaya belajar siswa dalam kategori visual, auditorial atau kinestetik). Tes hasil belajar yang digunakan berupa tes objektif berbentuk pilihan ganda dengan empat alternatif jawaban dengan satu jawaban benar yang terdiri dari 20 soal.

Uji coba instrumen dilakukan di kelas VIII B SMPN 14 Banjarmasin. Uji coba dilakukan untuk mengetahui apakah instrumen tes yang telah dibuat telah memenuhi syarat-syarat instrumen yang baik, yaitu validitas isi, daya beda, tingkat kesukaran dan reliabel. Untuk instrumen tes hasil belajar, mengacu pada kriteria yaitu validitas isi, daya pembeda ( $\mathrm{D} \geq 0,3)$, tingkat kesukaran $(0,3 \leq \mathrm{P} \leq 0,7)$, dan reliabilitas ( $111 \geq 0,7)$, dari 35 butir soal yang diujicobakan diperoleh 20 butir soal yang digunakan sebagai alat pengambil data hasil belajar matematika siswa. Uji prasyarat analisis yaitu uji normalitas dengan Lilliefors dan uji homogenitas dengan uji Bartlett. Uji analisis data yang digunakan yaitu analisis variansi dua jalan dengan sel tak sama.

\section{HASIL DAN PEMBAHASAN}

Hasil uji keseimbangan terhadap data kemampuan awal siswa diperoleh bahwa ketiga populasi mempunyai kemampuan awal yang sama. Data kemampuan awal siswa yaitu nilai ulangan akhir semester matematika kelas VIII semester gasal tahun pelajaran 2017/2018 yang diambil sebelum dilakukan penelitian baik pada kelompok eksperimen 1, pada kelompok eksperimen 2, maupun pada kelompok kontrol. Pada kelompok eksperimen 1 diberi perlakuan model pembelajaran berbasis TIK menggunakan metode discovery learning dengan peer assessment, pada kelompok eksperimen 2 diberi perlakuan model pembelajaran berbasis TIK menggunakan metode discovery learning, dan pada kelompok kelas kontrol diberi perlakuan menggunakan model pembelajaran konvensional. Setelah eksperimen, didapatkan data hasil belajar matematika. Data hasil belajar matematika siswa untuk kelompok eksperimen yang pertama berasal dari 31 siswa kelas VIII E SMPN 14 Banjarmasin, data hasil belajar matematika siswa untuk kelompok eksperimen yang kedua berasal dari 32 siswa kelas VIII D SMPN 14 Banjarmasin, dan data hasil belajar matematika siswa untuk kelompok kontrol berasal dari 30 siswa kelas VIII F SMPN 14 Banjarmasin. Hasil dari pengelompokan siswa berdasarkan model pembelajaran dapat disajikan dalam tabel berikut ini. 
Tabel 1. Deskripsi Data Hasil Belajar Siswa

\begin{tabular}{|c|l|c|c|c|}
\hline No. & \multicolumn{1}{|c|}{ Kelompok } & Rerata & $\begin{array}{c}\text { Standar } \\
\text { deviasi }\end{array}$ & N \\
\hline 1. & $\begin{array}{l}\text { Eksperimen 1 (Model } \\
\text { pembelajaran berbasis TIK } \\
\text { menggunakan metode discovery } \\
\text { learning disertai dengan peer } \\
\text { assessment) }\end{array}$ & 74,17 & 13,40 & 31 \\
\hline 2. & $\begin{array}{l}\text { Eksperimen 2 (Model } \\
\text { pembelajaran berbasis TIK } \\
\text { menggunakan metode discovery } \\
\text { learning ) }\end{array}$ & 68,58 & 13,50 & 32 \\
\hline 3. & Kontrol (Model Konvensional) & 61,11 & 13,21 & 30 \\
\hline
\end{tabular}

Sebelum dilakukan analisis variansi dua jalan, terlebih dahulu dilakukan uji normalitas dan uji homogenitas sebagai uji prasyarat analisis variansi. Uji normalitas digunakan untuk mengetahui apakah data variabel terikat yaitu hasil belajar matematika berasal dari populasi normal. Uji normalitas hasil belajar dalam penelitian ini meliputi: (1) kelompok siswa dengan model pembelajaran berbasis TIK menggunakan metode discovery learning disertai dengan peer assessment $\left(a_{1}\right)$; (2) kelompok siswa dengan model pembelajaran berbasis TIK menggunakan metode discovery learning $\left(a_{2}\right)$; (3) kelompok siswa dengan model pembelajaran konvensional $\left(a_{3}\right)$. Uji Normalitas menggunakan uji Lilliefors dengan tingkat signifikansi $\alpha=0,05$. Rangkuman uji normalitas sebagai berikut:

Tabel 2. Rangkuman Uji Normalitas Data Hasil Belajar Matematika

\begin{tabular}{|c|c|c|c|c|c|c|}
\hline No & Kelompok & $\mathbf{L}_{\text {obs }}$ & $\mathbf{n}$ & $\mathbf{L}_{\text {Tabel }}=\mathbf{L}_{(\boldsymbol{\alpha} ; \boldsymbol{n})}$ & $\begin{array}{c}\text { Keputusan } \\
\mathbf{u j i}\end{array}$ & Ket \\
\hline 1. & $a_{1}$ & 0,076463 & 31 & 0,15366 & $\mathrm{H}_{0}$ diterima & Normal \\
\hline 2. & $a_{2}$ & 0,096146 & 32 & 0,15545 & $\mathrm{H}_{0}$ diterima & Normal \\
\hline 3. & $a_{3}$ & 0,062917 & 30 & 0,15174 & $\mathrm{H}_{0}$ diterima & Normal \\
\hline
\end{tabular}

Berdasarkan tabel di atas, masing-masing sampel harga $\mathrm{L}_{\mathrm{obs}}<\mathrm{L}_{\text {tabel }}=\mathrm{L}_{(\alpha ; n)}$, dengan deaerah kritik DK $=\left\{\mathrm{L} \mid \mathrm{L}>\mathrm{L}_{(0,05 ; \mathrm{n})}\right\}$, sehingga $\mathrm{L}_{\mathrm{obs}} \notin \mathrm{DK}$ maka berarti pada taraf signifikansi $\alpha$ sebesar 5\% semua hipotesis nol diterima. Ini berarti sampel berasal dari populasi yang berdistribusi normal.

Prosedur uji homogenitas hasil belajar dalam penelitian ini menggunakan uji Bartlett yang meliputi kelompok $a_{1}, a_{2}$ dan $a_{3}$. Berikut ini merupakan hasil 
perhitungan uji homogenitas yang menggunakan uji Bartlett dengan tingkat signifikansi $\alpha=0,05$ :

Tabel 3. Rangkuman Uji Homogenitas Variansi

\begin{tabular}{|c|c|c|l|c|}
\hline Populasi & $\chi_{\text {obs }}^{2}$ & $\chi_{\text {tabel }}^{2}$ & Keputusan & Kesimpulan \\
\hline kelompok $a_{1,} a_{2}$ dan $a_{3}$ & 0,072102 & 5,991 & $\mathrm{H}_{0}$ diterima & Homogen \\
\hline
\end{tabular}

Dari hasil analisis uji homogenitas variansi hasil belajar matematika di atas, tampak bahwa nilai $\chi_{o b s}^{2}$ masing-masing kelompok lebih kecil dari $\chi_{\text {tabel }}^{2}=5,991$ dan daerah kritik uji ini DK $=\left\{\chi^{2} \mid \chi^{2}>5,991\right\}$, sehingga $\chi_{o b s}^{2} \notin \mathrm{DK}$ maka berarti pada taraf signifikansi $\alpha$ sebesar 5\% hipotesis nol diterima. Hal ini berarti bahwa populasipopulasi memiliki variansi yang sama (homogen).

Selanjutnya dilakukan uji analisis variansi dua jalan dengan sel tak sama. Rangkuman uji analisis variansi disajikan pada Tabel 4.

Tabel 4. Rangkuman Analisis Variansi Dua Jalan

\begin{tabular}{|c|c|c|c|c|c|c|}
\hline Sumber & JK & $\mathbf{d k}$ & $\mathbf{R K}$ & $\mathbf{F}_{\text {obs }}$ & $\mathbf{F} \alpha$ & $\begin{array}{c}\text { Keputusa } \\
\mathbf{n} \text { uji }\end{array}$ \\
\hline $\begin{array}{c}\text { Model pembelajaran } \\
\text { (A) }\end{array}$ & 4239,37 & 2 & 2341,54 & 12,8576 & 3,080 & $\begin{array}{c}\mathrm{H}_{0 \mathrm{~A}} \\
\text { ditolak }\end{array}$ \\
\hline Gaya Belajar (B) & 2342,18 & 2 & 1132,15 & 7,23412 & 3,080 & $\begin{array}{c}\mathrm{H}_{0 \mathrm{~B}} \\
\text { ditolak }\end{array}$ \\
\hline Interaksi (AB) & 214,2657 & 4 & 59,2134 & 0,43156 & 2,365 & $\begin{array}{c}\mathrm{H}_{0 \mathrm{AB}} \\
\text { diterima }\end{array}$ \\
\hline Galat (G) & 14158,21 & 84 & 169,2251 & - & - & - \\
\hline Total & 28625,35 & 92 & - & - & - & - \\
\hline
\end{tabular}

Kesimpulan analisis variansi dua jalan dengan sel tak sama berdasarkan Tabel 4. adalah (1) Pada efek utama antar baris (A), siswa-siswa yang dikenai dengan model pembelajaran berbasis TIK menggunakan metode discovery learning dengan peer assessment, pembelajaran berbasis TIK menggunakan metode discovery learning, dan konvensional memberikan efek yang berbeda terhadap hasil belajar matematika siswa. (2) Pada efek interaksi (AB), tidak terdapat interaksi antara model pembelajaran dan gaya belajar siswa terhadap hasil belajar matematika siswa.

Berdasarkan anava dua jalan diperoleh bahwa $\mathrm{H}_{0 \mathrm{~A}}$ ditolak, sehingga perlu dilakukan uji lanjut pasca analisis variansi dengan metode Scheffe' untuk uji 
komparasi antar baris. Rangkuman perhitungan uji lanjut rerata antar baris disajikan pada Tabel 5.

Tabel 5. Rangkuman Hasil Uji Komparasi Ganda Antar Baris

\begin{tabular}{|c|c|c|c|}
\hline $\mathbf{H}_{\mathbf{0}}$ & $\mathbf{F}_{\text {hit }}$ & $F_{0,05 ; 2,84}$ & Keputusan Uji \\
\hline$\mu_{1 .}=\mu_{2 .}$ & 6,21783 & 3,080 & $\mathrm{H}_{0}$ ditolak \\
\hline$\mu_{1 .}=\mu_{3 .}$ & 24,7645 & 3,080 & $\mathrm{H}_{0}$ ditolak \\
\hline$\mu_{2 .}=\mu_{3 .}$ & 13,89724 & 3,080 & $\mathrm{H}_{0}$ ditolak \\
\hline
\end{tabular}

Berdasarkan hasil analisis variansi dua jalan dengan sel tak sama untuk efek utama faktor $\mathrm{A}$ (model pembelajaran) diperoleh harga statistik uji $\mathrm{F}_{\mathrm{a}}=12,8576$ dan

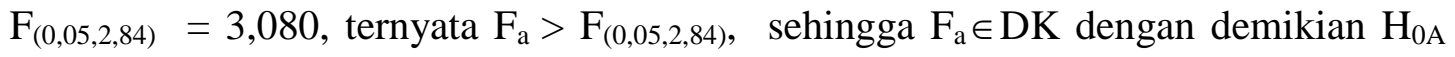
ditolak. Karena $\mathrm{H}_{0 \mathrm{~A}}$ ditolak maka perlu dilakukan uji lanjut anava yaitu uji komparasi ganda. Berdasarkan Tabel 5 hasil uji komparasi antar baris pada masing-masing kategori model pembelajaran dan Tabel 1, diperoleh simpulan bahwa hasil belajar siswa yang diberi perlakuan model pembelajaran berbasis TIK menggunakan metode discovery learning dengan peer assessment lebih baik dari hasil belajar siswa yang diberi model pembelajaran berbasis TIK menggunakan metode discovery learning dan model pembelajaran konvensional. Selain itu, hasil belajar siswa yang diberi perlakuan model pembelajaran berbasis TIK menggunakan metode discovery learning lebih baik dari hasil belajar siswa yang diberi model pembelajaran konvensional. Hal ini dimungkinkan karena model pembelajaran berbasis TIK menggunakan metode discovery learning dengan peer assessment merupakan model pembelajaran yang mendorong siswa untuk aktif dalam pembelajaran. Dalam model pembelajaran berbasis TIK menggunakan metode discovery learning dengan peer assessment siswa dituntut untuk aktif dalam belajar materi bangun ruang dengan pembelajaran berbasis komputer yang inovatif. Selain itu ditambah lagi dengan adanya penilaian teman sejawat siswa (peer assessment) yang digunakan untuk mendapatkan partisipasi siswa melalui tulisan untuk dapat lebih mengoptimalkan kemampuan berpikir siswa dalam hal menilai teman sejawatnya secara tertulis. Sedangkan pada model pembelajaran konvensional guru lebih mendominasi pembelajaran sehingga siswa kurang aktif dalam memperoleh informasi yang disampaikan. Selain itu ada kecendrungan siswa acuh untuk bertanya pada gurunya apabila ada materi yang belum mereka pahami dan pembelajaran cenderung monoton sehingga siswa merasa jenuh dalam belajar. Menurut Muhibbin Syah (2008:165) seseorang siswa yang sedang dalam kejenuhan sistem akalnya tidak dapat bekerja sebagaimana yang diharapkan dalam memproses item-item informasi sehingga prestasi belajar dapat menurun. Sehingga dapat disimpulkan bahwa siswa yang diberi model pembelajaran berbasis TIK menggunakan metode discovery learning dengan peer assessment mempunyai hasil belajar matematika yang lebih baik dari siswa yang diberi model pembelajaran konvensional. 
Asy'ari \& Zulkarnain M.R. / LENTERA Jurnal Ilmiah Kependidikan Vol. 14 No.2 (2019) 11-21

\section{SIMPULAN DAN SARAN}

\section{A. Simpulan}

Berdasarkan hasil penelitian pengembangan, maka dapat disimpulkan syntax untuk model pembelajaran berbasis TIK menggunakan metode discovery learning dengan peer assessment (penilaian teman sejawat) adalah sebagai berikut. 1) Pendahuluan, pada tahap ini guru menyampaikan tujuan pembelajaran dan motivasi kepada siswa. 2) Eksplorasi, Guru menjelaskan materi pelajaran tentang bangun ruang sisi datar dengan menggunakan media pembelajaran berbantuan komputer yang diproyeksikan menggunakan LCD. Pada tahap ini guru memberikan stimulus bisa berupa pertanyaan-pertanyaan yang merangsang keingintahuan siswa maupun masalah yang berkaitan dengan materi yang disajikan dalam LKS. Pada langkah ini guru membimbing siswa untuk menemukan konsep dari materi yang dipelajari dengan menggunakan LKS dengan metode discovery, LKS ini mengajak siswa untuk mengkonstruksi sendiri pengetahuannnya agar siswa dapat menemukan konsep dari materi yang dipelajari. Dalam LKS, siswa diarahkan untuk menjawab pertanyaanpertanyaan yang membimbing atau mengarahkan siswa untuk menemukan konsep dari materi yang sedang dipelajari. Misalnya siswa akan menemukan apa yang dimaksud dengan diagonal bidang, diagonal ruang, bidang diagonal, dan lain sebagainya yang terkait dengan materi bangun ruang sisi datar. Pada tahapan ini guru hanya berperan sebagai fasilitator. 3) Guru memberikan soal esensial yang bisa dikerjakan dalam waktu sekitar 10-15 menit, dan menyuruh siswa untuk memikirkan dan mengerjakan secara mandiri. 4) Setelah siswa mengerjakan soal, guru memintanya untuk berpasangan. Pada proses ini guru akan membagikan rubrik atau pedoman penilaian yang akan digunakan siswa untuk melakukan peer assessment (penilaian sejawat). Ketika proses peer assessment (penilaian sejawat) dilakukan, guru tetap memberikan bimbingan jika ada siswa yang belum paham. 5) Setelah proses penilaian sejawat selesai, beberapa pasangan mempresentasikan hasil pengetahuan yang didapat pada proses penilaian sejawat. 6) Penutup, pada tahap ini hasil peer assessment (penilaian sejawat) dikembalikan kepada pemiliknya untuk dijadikan koreksi bersama dan selanjutnya dikumpulkan kepada guru untuk diperiksa ulang dan diberi umpan balik, yang kemudian dikembalikan lagi kepada siswa pada pertemuan berikutnya. Pada tahap ini guru juga bisa memberikan pekerjaan rumah sebagai latihan soal untuk belajar siswa di rumah.

Berdasarkan hasil penelitian eksperimental semu di kelas VIII SMPN 14 Banjarmasin dapat disimpulkan sebagai berikut. Berdasarkan hasil penelitian eksperimental semu dapat disimpulkan bahwa hasil belajar siswa yang diberi perlakuan model pembelajaran berbasis TIK menggunakan metode discovery learning dengan peer assessment lebih baik dari hasil belajar siswa yang diberi perlakuan model pembelajaran berbasis TIK menggunakan metode discovery learning dan model pembelajaran konvensional, dan hasil belajar siswa yang diberi perlakuan model pembelajaran berbasis TIK menggunakan metode discovery learning lebih baik dari hasil belajar siswa yang diberi perlakuan dengan menggunakan model pembelajaran konvensional. 


\section{B. Saran}

Berdasarkan simpulan Berdasarkan simpulan, adapun saran dari hasil penelitian ini adalah bagi pendidik hendaknya model pembelajaran berbasis TIK menggunakan metode discovery learning dengan peer assessment ataupun model pembelajaran berbasis TIK dapat dijadikan sebagai salah satu referensi dalam pembelajaran matematika di kelas, karena berdasarkan hasil penelitian yang dilakukan di kelas VIII SMPN 14 Banjarmasin kedua model tersebut memberikan hasil belajar yang lebih baik dibandingkan model pembelajaran konvensional.

Ucapan terima kasih kepada Kementerian Riset, Teknologi, dan Pendidikan Tinggi yang telah membiayai penelitian ini melalui hibah Penelitian Dosen Pemula (PDP) tahun anggaran 2018.

\section{DAFTAR RUJUKAN}

Balım, A. G. (2009). "The Effects of Discovery Learning on Students' Success and Inquiry Learning Skills". Egitim Arastirmalari Eurasian Journal of Educational Research, 35: 1-20.

Dryden, G \& Vos, J. (2003). Revolusi Cara Belajar (The Learning Revolution). Bandung: Kaifa.

Jamilah. (2013). Eksperimentasi Pendekatan Pendidikan Matematika Realistik (PMR) dengan Metode Discovery Learning Pada Materi Pokok Bnetuk Aljabar Ditinjau dari Kemampuan Komunikasi Matematik Siswa kelas VII SMP Negeri Se-Kota Pontianak. Tesis. Tidak Diterbitkan. Surakarta: Universitas Sebelas Maret.

Looney, J. W. (2009). “Assessment and Innovation in Education”, OECD Education Working Papers, 24(3): 5-8

Lu, J \& Law, N. (2011). Online Peer Assessment: Effects of Cognitive and Affective Feedback. Faculty of Education, The University of Hongkong. No.40: 257275.

Muhibbin Syah. (2008). Psikologi Pendidikan dengan pendekatan Baru. Bandung : Remaja Rosdakarya.

Nick, Z. Z. (2010). Innovative Assessment For Learning Enhancement : Issue And Practices. Technological Education, Institute of Piraeus. Vol. 3, No. 1

Suryadi, Ace. (2007). Pemanfaatan ICT dalam Pembelajaran. Jurnal Pendidikan Terbuka dan Jarak Jauh. Volume 8, Nomor 1, Maret 2007,83-98. 